\title{
Maintaining postharvest quality of cold stored 'Hass' avocados by altering the fatty acids content and composition with the use of natural volatile
} compounds - methyl jasmonate and methyl salicylate

\author{
Marcin Glowacz, ${ }^{\mathrm{a}, \mathrm{b}^{*}}$ Malick Bill, ${ }^{\mathrm{b}}$ Peter P. Tinyane ${ }^{\mathrm{b}}$ and Dharini Sivakumar ${ }^{\mathrm{b}}$ \\ ${ }^{a}$ Natural Resources Institute, University of Greenwich, Chatham, ME4 4TB, UK \\ ${ }^{b}$ Postharvest Technology Group, Department of Crop Sciences, Tshwane University of Technology, Private Bag \\ X680, Pretoria West 0001, South Africa \\ *Corresponding author.
}

Tel.: +44 (0) 1634 883564, e-mail address: M.M.Glowacz@greenwich.ac.uk; SivakumarD@tut.ac.za

\begin{abstract}
BACKGROUND: Low temperature is often used to reduce metabolic processes and extend the storage of fruit, however, in the case of avocado the temperature below $3{ }^{\circ} \mathrm{C}$ would often result in development of physiological disorders associated with chilling injury. The objective of this study was to investigate the ability of methyl jasmonate (MeJA) and methyl salicylate (MeSA) vapours to alleviate the chilling injury in 'Hass' avocado fruit kept at $2{ }^{\circ} \mathrm{C}$ for $21 \mathrm{~d}$ followed by $6-7 \mathrm{~d}$ shelf-life at $20^{\circ} \mathrm{C}$, simulating supply chain conditions.

RESULTS: The incidence and severity of chilling injury was significantly reduced in MeJA and MeSA exposed fruit, especially at $100 \mu \mathrm{mol} \mathrm{l}^{-1}$. The mechanism involved improved membrane integrity via alteration of the fatty acids content and composition, down-regulation of LOX gene expression and reduced activity of lipoxygenase.
\end{abstract} CONCLUSION: Methyl jasmonate and methyl salicylate have the potential for being used with 'Hass' avocado fruit shipped at low temperature by reducing their susceptibility to chilling injury.

Keywords: Persea americana Mill., chilling injury, fatty acids, methyl jasmonate, methyl salicylate, supply chain

\section{INTRODUCTION}

The avocado fruit (Persea americana Mill.) is becoming more and more popular among the consumers, especially due to being rich in nutrients associated with health benefits. ${ }^{1}$ The fruit also contains high level of fatty acids, i.e. oleic (a monounsaturated omega-9 fatty acid, C18:1) and palmitic (a saturated fatty acid, C16:0) acid, ${ }^{2-4}$ while the sugar content is relatively low.

According to the latest (2015) food trade and supply chain directory (www.foodtradesa.co.za), the European Union, and United Kingdom in particular, is the biggest export market for the South African avocados. 
The fruit are transported by the sea freight, which means that it may take up to four weeks from harvest before reaching the consumer. ${ }^{5}$ The standard shipping temperature used by the South African avocado industry for 'Hass' avocados is around $5.5{ }^{\circ} \mathrm{C}$; however, to prevent 'soft landing' at the destination port, industry often uses an ethylene inhibitor 1-methylcyclopropene (1-MCP) during the shipment under controlled atmosphere conditions $\left(2-5 \% \mathrm{O}_{2}, 5-10 \% \mathrm{CO}_{2}\right) \cdot{ }^{6,7}$ Unfortunately, the application of 1-MCP causes problems, especially with the 'Hass' avocado fruit destined for the 'ready to eat' ripening programmes, due to uneven ripening (firmness) and poor fruit colouration. ${ }^{8}$ The fact that good appearance and the right firmness of the produce have huge impact on consumers' willingness to buy the fruit has been highlighted by several authors. ${ }^{9,10}$ Furthermore, the delayed ripening caused by 1 -MCP aggravates the incidence of postharvest fungal rots. ${ }^{11}$

The South African avocado industry is also planning to expand into the new markets, e.g. US. This would require disinfestation treatment before the fruit could enter the country. The exposure to temperatures ranging from 1.1 to $2.2{ }^{\circ} \mathrm{C}$ for $14-18 \mathrm{~d}$ has been proven to control fruit flies and thus could be used as a cold quarantine treatment. ${ }^{12}$ Low temperatures are often used to reduce metabolic processes and extend storage life of the fruit, however, during the extended period of cold storage at temperature less than $3{ }^{\circ} \mathrm{C}$ avocado fruit are likely to develop physiological disorders associated with chilling injury, ${ }^{13-15}$ which may be expressed in several ways, such as skin blackening, pitting or sunken lesions, lenticels damage, and mesocarp discolouration, e.g. internal browning and/or grey pulp. The main problem with the internal disorders in the ripe fruit is the fact that it is not possible to notice them from the outside. Thus, it is not surprising that the lack of internal defects has been identified $^{16}$ among the key aspects of avocado quality that ensure consumers' satisfaction.

Internal browning is related to textural quality loss due to alterations in membranes permeability, allowing polyphenol oxidase (PPO) to come into contact with its substrates - phenolic compounds. PPO catalyses the oxidation of phenols into quinones that are subsequently polymerised into brown pigments. ${ }^{6,17}$

The postharvest use of jasmonates and salicylates seems to have unexplored potential. ${ }^{18}$ Their ability to alleviate chilling injury has been demonstrated in numerous tropical and sub-tropical fruit, i.e. in guava, ${ }^{19}$ loquat, ${ }^{20,21}$ mango, ${ }^{22,23}$ papaya, ${ }^{24}$ peach,,${ }^{25,26}$ and pomegranate. ${ }^{27}$ It has also been reported that dipping 'Hass' avocado fruit in $2.5 \mu \mathrm{mol}^{-1}$ methyl jasmonate solution for $30 \mathrm{~s}$ reduced the development of chilling injury in fruit subsequently stored for 2 weeks at $1{ }^{\circ} \mathrm{C}^{28}$ and 4 weeks at $2{ }^{\circ} \mathrm{C},{ }^{29}$ respectively. To the best of our knowledge, there are only two reports ${ }^{28,29}$ on the use of methyl jasmonate with avocado fruit mainly focused on dipping treatment, with very little information on the vapour treatment. ${ }^{29}$ There is also an absolute lack of information in the literature on the effects of salicylates on avocado fruit quality during low temperature storage. 
Thus, the objective of this study was to investigate the effect of methyl jasmonate (MeJA) and methyl salicylate (MeSA) vapours exposure at two concentrations (10 and $100 \mu \mathrm{mol}^{-1}$ ) on i) chilling injury incidence and severity, ii) flesh colour, iii) activity of L-phenylalanine ammonia-lyase (PAL), polyphenol oxidase (PPO), and lipoxygenase (LOX) enzymes iv) expression of PAL and LOX genes and v) fruit composition in terms of its phytonutrient content (fatty acids, phenolic compounds, and D-mannoheptulose) in 'Hass' avocado fruit kept at 2 ${ }^{\circ} \mathrm{C}$ for $21 \mathrm{~d}$ followed by 6-7 d shelf-life at $20{ }^{\circ} \mathrm{C}$, simulating quarantine treatment and supply chain conditions.

\section{EXPERIMENTAL}

\section{Plant material and handling}

Freshly harvested, unblemished 'Hass' avocado fruit were obtained from Koeltehof Packers (Nelspruit, Mpumalanga province, South Africa) at commercial maturity. Fruit were transported to the laboratory and then i) left untreated - control ii) dipped for $5 \mathrm{~min}$ in $0.05 \%$ prochloraz $^{\circledR}$ - the commercial treatment; iii) exposed to methyl jasmonate (MeJA) or methyl salicylate (MeSA) vapours at two concentrations of 10 and $100 \mu \mathrm{mol} \mathrm{l}^{-1}$ for 24 h at $20.0 \pm 0.5^{\circ} \mathrm{C}$.

After placing the fruit in a 101 air-tight sealable plastic containers container, the appropriate volume of MeJA or MeSA to reach the desired concentration of 10 and $100 \mu \mathrm{mol} \mathrm{l}^{-1}$, respectively was spotted on the Petri dish at the bottom of the container, as previously described for thyme oil fumigation. ${ }^{30}$ The container was immediately hermetically-sealed and solutions were left to evaporate over the $24 \mathrm{~h}$ period. Control and prochloraz treated fruit were also kept in similar sealed containers. Avocado fruit were subsequently stored for $21 \mathrm{~d}$ at $2.0 \pm 0.2$ ${ }^{\circ} \mathrm{C}$, respectively to simulate the shipping conditions, and thereafter kept at $20.0 \pm 0.5{ }^{\circ} \mathrm{C}, \mathrm{RH} 70 \%$ for $6-7 \mathrm{~d}$ to simulate the retail shelf-life conditions. Each treatment had six replicate boxes, each containing eighteen fruit, i.e. 108 fruit per treatment, equalling to a total of 648 fruit per trial. The experiment was repeated twice.

\section{Evaluation of chilling injury incidence and severity}

The incidence of chilling injury was recorded as a $\%$ of fruit with signs of mesocarp discolouration due to cold damage. The severity of the chilling injury was rated according to the chilling index (Fig. 1) on a scale from 0 to 5 , at the 'ripe and ready to eat' stage, i.e. after $21 \mathrm{~d}$ of cold storage plus $6-7 \mathrm{~d}$ shelf-life at $20{ }^{\circ} \mathrm{C}$. 


\section{Disease incidence}

At the 'ripe and ready to eat' stage fruit were assessed for signs of rotting (anthracnose), by giving them a score of 0 or $1-$ no/ signs of rotting, respectively. Disease incidence was expressed as the proportion (\%) of fruit showing signs of rotting out of the total number of fruit in each treatment.

\section{Physical properties of the fruit}

Flesh firmness was determined along the equator of the fruit using a Chatillon Penetrometer, Model DFM50 (Ametek, Largo, Florida, USA) with an $8 \mathrm{~mm}$ diameter flat-head stainless steel cylindrical probe - puncture test. ${ }^{31}$ Flesh colour measurements were taken at three points from each half of the fruit with a Minolta Chroma meter CR 0-2000 (Minolta Camera Co. Ltd, Tokyo, Japan), calibrated with manufacturer's standard white plate. ${ }^{32}$

\section{Biochemical analyses}

Determination of PAL activity was conducted following the method previously described in Sellamuthu et $a l .{ }^{33}$, with some modifications. Fruit tissue sample $(1.0 \mathrm{~g})$ was homogenised with borate buffer $(100 \mathrm{mmol}$ $\mathrm{l}^{-1}$, pH 8.8) containing $5 \mathrm{mmol} \mathrm{l}^{-1}$ of $\beta$-mercaptoethanol and $2 \mathrm{mmol}^{-1}$ EDTA. $75 \mu \mathrm{l}$ of the extract was then incubated for $60 \mathrm{~min}$ at $37^{\circ} \mathrm{C}$ with $150 \mu \mathrm{l}$ of borate buffer $\left(50 \mathrm{mmol} \mathrm{l}^{-1}, \mathrm{pH} 8.8\right)$ containing $20 \mathrm{mmol} \mathrm{l}^{-1} \mathrm{~L}$ -

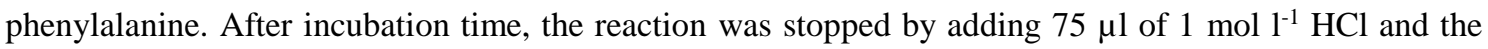
production of cinnamate was spectrophotometrically determined at $290 \mathrm{~nm}$ (Zenyth 200rt Microplate Reader UK-Biochrom Ltd.). The specific activity of enzyme was expressed as nmol cinnamic acid h $\mathrm{h}^{-1} \mathrm{mg}^{-1}$ of protein.

Phenolic acids ( $p$-coumaric acid, ferulic acid, caffeic acid, protocatechuic acid, 4-hydroxybenzoic acid, and pyrogallol) content in the fruit mesocarp was determined according to the method of Zhang and $\mathrm{Zuo}^{34}$ with some modifications. Freeze-dried samples $(5 \mathrm{~g})$ were extracted with $40 \mathrm{ml}$ of $70 \%(\mathrm{v} / \mathrm{v})$ methanol $(\mathrm{MeOH})$. After extraction $100 \mu \mathrm{l}$ of naphthol $\left(1 \mu \mathrm{mol} \mathrm{l}^{-1}\right)$ were added as an internal standard. The mixture was agitated and subsequently incubated for $2 \mathrm{~h}$ at $60{ }^{\circ} \mathrm{C}$. The samples were centrifuged and the resulting $500 \mu \mathrm{l}$ of supernatants were dried in a SpeedVac ${ }^{\mathrm{TM}}$ (Thermo Fisher Scientific, Massachusetts, US). Dried samples were reconstituted with $150 \mu$ l of acetonitrile, followed by $50 \mu 1$ BSTFA [N,O-bis (trimethylsilyl) trifluoroacetamide)] and $1 \%$ TMCS (trimethylchlorosilane). BSTFA and TMCS were used as silylation reagents. The mixture was agitated and then derivatised by incubating for $1 \mathrm{~h}$ at $80{ }^{\circ} \mathrm{C}$. After incubation, the mixture was agitated again and then transferred into GC vials. One $\mu$ l was injected into a GC/MS (7890A Gas Chromatograph with 5975C Mass Spectrometer; Agilent Chemetrix (Pty) Ltd, 
Johannesburg, South Africa). Phenolic acids separation was performed on a DB-5ms Ultra Inert, $30 \mathrm{~m} \mathrm{x}$ $0.25 \mathrm{~mm}, 0.25 \mu \mathrm{m}$ column. The GC/MS conditions and run parameters were set according to Zhang and

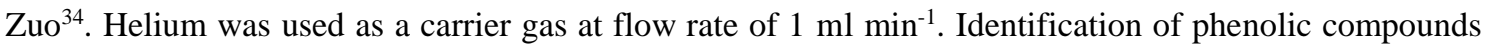
was achieved by matching the peaks retention times (RT) with authentic standards. The individual compounds were quantified by calculating their peak areas, and their content was expressed on dry weight (DW) basis.

The polyphenol oxidase (PPO) activity was determined using a method described by Soliva et al. ${ }^{35}$ with minor modifications. The $20 \mu \mathrm{l}$ of enzyme and $200 \mu \mathrm{l}$ buffered substrate $\left(0.1 \mathrm{~mol} \mathrm{l}^{-1}\right.$ sodium phosphate, $\mathrm{pH} 7.0$ and $0.05 \mathrm{~mol} \mathrm{l}^{-1}$ catechol) were mixed thoroughly. Afterwards, the increase in absorbance at 410 nm was measured for 5 min (SPECTROstarNano Microplate Reader, BMG LABTECH, Ortenberg,

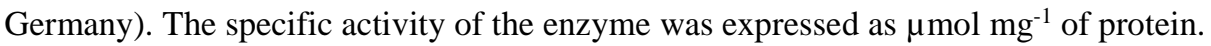

For the determination of fatty acids, i.e. oleic acid (C18:1, a monounsaturated omega-9 fatty acid), palmitic acid (C16:0, a saturated fatty acid), palmitoleic acid (C16:1, a monounsaturated omega-7 fatty acid), and linoleic acid (18:2, a polyunsaturated omega- 6 fatty acid) $1 \mathrm{~g}$ of lyophilised mesocarp tissue powder was homogenised with $30 \mathrm{ml}$ of hexane for $30 \mathrm{~s}$. Oil extraction was performed following the method used by Meyer and Terry ${ }^{36}$. Avocado oil extract was dissolved in $2 \mathrm{ml}$ of hexane and mixed with $0.2 \mathrm{ml}$ of $0.2 \mathrm{~mol} \mathrm{l}^{-1}$ potassium hydroxide $(\mathrm{KOH})$ in methanol. The mixture was shaken vigorously for $30 \mathrm{~s}$, and left until the upper hexane layer became clear. This layer containing methyl esters was decanted and diluted 1:100 (v/v) with fresh hexane directly prior to the injection into the GC/MS. Fatty acids separation was performed on a HP-88 112-8867, $60 \mathrm{~m} \times 0.25 \mathrm{~mm}, 0.20 \mu \mathrm{m}$ column using helium as a carrier gas at constant flow rate of $1.4 \mathrm{ml} \mathrm{min}^{-1}$. The GC conditions and run parameters were set up according to Meyer and Terry $^{36}$. Fatty acids were identified and quantified using known concentrations of the standards, i.e. methyl palmitate, methyl oleate and methyl linoleate. Fatty acids content was expressed on dry weight (DW) basis.

LOX activity was determined following the method used by Maalekuu et al. ${ }^{37}$. Briefly, avocado pulp tissue (15 g) was homogenized in $30 \mathrm{ml}$ of phosphate buffer $\left(0.05 \mathrm{~mol} \mathrm{l}^{-1}, \mathrm{pH} 7.0\right)$ for $1 \mathrm{~min}$ using a Janke \& Kunkel IKA Labortechnik ultra-turrax T25 homogenizer (IKA, Germany). The homogenate was centrifuged at $10,000 \times g$ for $15 \mathrm{~min}$ at $4{ }^{\circ} \mathrm{C}$ and filtered. Turbidity was cleared with a few drops of $2 \mathrm{~N}$ $\mathrm{NaOH}$. The crude extract was mixed with the substrate - linoleic acid $(20 \mu \mathrm{l})$ in a spectrophotometer cuvette containing $3 \mathrm{ml}$ of $0.2 \mathrm{~mol} \mathrm{l}^{-1}$ phosphate buffer, $\mathrm{pH} 6.5$ and the absorbance was measured at $234 \mathrm{~nm}$ at $6 \mathrm{~s}$ intervals for 1 min using spectrophotometer (SPECTROstarNano Microplate Reader, BMG LABTECH, 
Ortenberg, Germany). The rate of formation of conjugated diene reaction products was measured as an increase in absorbance at $234 \mathrm{~nm}$, and specific enzyme activity was calculated and expressed as $\mathrm{U} \mathrm{mg}^{-1}$ protein $\mathrm{h}^{-1}$. Protein concentration was determined by the method of Bradford ${ }^{38}$.

Mannoheptulose was extracted following the method of Roessner et al. ${ }^{39}$ with some modifications. Freeze-dried powder $(100 \mathrm{mg})$ was dissolved in $1.4 \mathrm{ml}$ of $100 \%$ methanol and $50 \mu \mathrm{l}$ of internal standard $\left(2 \mathrm{~g} \mathrm{l}^{-1}\right.$ ribitol (w/v) in water) was added. The mixture was agitated for $10 \mathrm{~s}$ and subsequently extracted for $15 \mathrm{~min}$ at $70{ }^{\circ} \mathrm{C}$. Samples were then centrifuged at $6000 \mathrm{x} g$ for $10 \mathrm{~min}$, and supernatants were transferred to the new tubes, where $750 \mu \mathrm{l}$ of dichloromethane and $1.5 \mathrm{ml}$ of distilled water were added. The tubes were agitated for $15 \mathrm{~s}$ and centrifuged again at $6000 \mathrm{x} g$ for $15 \mathrm{~min}$. Thereafter, $150 \mu \mathrm{l}$ of the upper (polar) phase were transferred into the new tubes and evaporated under nitrogen gas until reaching complete desiccation. For identification and quantification, the residue was re-suspended and derivatised for $2 \mathrm{~h}$ at $37{ }^{\circ} \mathrm{C}$ in $40 \mu \mathrm{l}$ of $20 \mathrm{~g} \mathrm{l}^{-1}$ methoxyamine hydrochloride in pyridine, with occasional shaking. This was followed by a 30 min incubation with $70 \mu 1 \mathrm{~N}$-methyl-N-(trimethylsilyl) trifluoroacetamide at $37^{\circ} \mathrm{C}$. After derivatisation, the samples were transferred into injection vials. Derivatised sugars were analysed using GC/MS with an Agilent J\&W DB-17 (50\%-phenyl)-methyl-polysil-oxane column 30 m x $250 \mu \mathrm{m}$ x 0.25

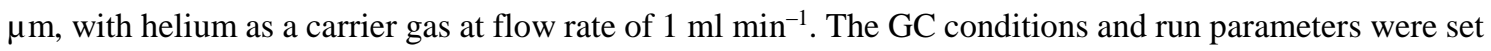
up according to Roessner et al. ${ }^{39}$. D-mannoheptulose sugar was identified and quantified by comparison of peak area with that of known standard, i.e. - D-mannoheptulose ( $\geq 99.0 \%$, Sigma Aldrich). Mannoheptulose content was expressed on dry weight (DW) basis.

\section{Gene expression analysis}

The analysis of expression of PAL and LOX genes was performed by qPCR, using a SYBR-green dye system, as described in Bill. ${ }^{40}$ The comparative $-\Delta \Delta \mathrm{C}_{\mathrm{t}}$ method was employed to evaluate the relative quantities of each of the amplified products. RNA Extraction: High quality total RNA was obtained from the fruit by using the total RNA plant mini kit (Zymo Research Corporation, Inqaba Biotech, South Africa). The RNA samples were analysed by electrophoresis in $1.8 \%(\mathrm{w} / \mathrm{v})$ agarose and formaldehyde denaturing gel. The purity of RNA purity was assessed using a BioPhotometer plus (Eppendorf Inc., Westbury, NY, USA). Reverse Transcription: A total of $1 \mu \mathrm{g}$ RNA was used for cDNA synthesis with RT-PCR, using transcriptor first strand cDNA synthesis kits (Roche Applied Science, Penzberg, Upper Bavaria, Germany). Primers and Reference Gene Selection: Specific primer sets were designed using the Primer3 software (http://biotools.umassmededu/bioapps/primer3_www.cgi) from the specific sequence of Persea americana 
deposited in the NCBI GenBank (Supplementary material). The primer pairs were chosen and validated in silico using primer BLAST specific analysis (http://www.ncbi.nlm.nih.gov/Blast.cgi) and then according to the melting profiles obtained from the quantitative real time PCR conditions (qPCR). To determine the specificity of the amplicons, melting curve analysis was performed over the range of temperatures from 60 to $95^{\circ} \mathrm{C}$. Quantitative RT-PCR: The qPCR was performed in UltraFlux ${ }^{\circledR}$ 96-well PCR Plate (SSI, Lodi, CA, USA) using the PowerUPтм Sybr ${ }^{\circledR}$ Green Master mix (Applied Biosystems, Austin, TX, USA) on a CFX Connect ${ }^{\mathrm{TM}}$ Real-Time PCR Detection System (Bio-Rad, Hercules, CA, USA) under the following conditions: an initial holding cycle $\left(10 \mathrm{~min}\right.$ at $\left.95^{\circ} \mathrm{C}\right)$, followed by 40 cycles of two steps of denaturation and annealing/extension ( $15 \mathrm{~s}$ at $95{ }^{\circ} \mathrm{C}$ and $60 \mathrm{~s}$ at $60{ }^{\circ} \mathrm{C}$ respectively). The PCR amplification was carried out in a total volume of $20 \mu \mathrm{l}$, containing $1 \mu \mathrm{l}$ of diluted (1:20) cDNA $\left(5 \mathrm{ng} \mathrm{l}^{-1}\right), 0.25 \mu \mathrm{mol} \mathrm{l^{-1 }}$ of each primer, and $10 \mu \mathrm{l}$ of Sybr ${ }^{\circledR}$ Green Master mix. The qPCR efficiency for each set of primers was determined using standard curves generated with five cDNA pool dilutions, i.e. undiluted, and at following dilutions: $1: 4,1: 16,1: 64$, and 1:256, respectively.

\section{Statistical analyses}

Avocado fruit were organised in 6 replicates of 18 fruit for each of the six treatments. Data are presented as mean values from a fully randomised design. Data were subjected to analysis of variance (ANOVA) to identify the treatments that had significant effect on the characteristics of 'Hass' avocado fruit, as determined with Fisher's Least Significant Difference (LSD) test with a significance level of 0.05, using GenStat $18^{\text {th }}$ Edition software.

\section{RESULTS AND DISCUSSION}

\section{Chilling injury incidence and severity}

'Hass' avocado fruit are susceptible to cold damage if kept at the temperature below $3{ }^{\circ} \mathrm{C},{ }^{13-15}$ thus it is not surprising that the majority (around $80 \%$ ) of the untreated fruit developed mesocarp disorders when held at $2{ }^{\circ} \mathrm{C}$ for $21 \mathrm{~d}$ followed by 6-7 d shelf-life at $20{ }^{\circ} \mathrm{C}$ (Fig. 2A). Chilling injury incidence was also high (above $60 \%$ ) in fruit treated with prochloraz. On the other hand, incidence of chilling injury was substantially reduced to around $20 \%$ in fruit treated with MeJA or MeSA at $100 \mu \mathrm{mol} \mathrm{1}^{-1}$. A reduction in chilling injury was a bit less pronounced at the lower concentration of $10 \mu \mathrm{mol} \mathrm{l}^{-1}$. The severity of chilling injury (chilling index) across the batches of fruit was significantly reduced in fruit exposed to MeJA at 10 $\mu \mathrm{mol} \mathrm{l}^{-1}$ (1.6) or $100 \mu \mathrm{mol} \mathrm{l} \mathrm{l}^{-1}(1.3)$ and MeSA at $10 \mu \mathrm{mol} \mathrm{l}^{-1}$ (1.0) or $100 \mu \mathrm{mol} \mathrm{l}^{-1}$ (1.1) when compared with untreated fruit (2.6) and those treated with prochloraz (2.2). 
Reduced chilling injury in avocado fruit exposed to MeJA and MeSA is in agreement with majority of studies reviewed by Glowacz and Rees ${ }^{18}$ where numerous tropical and sub-tropical fruit were exposed to MeJA or MeSA prior to storage, and also with those where 'Hass' avocado fruit were dipped in $2.5 \mu$ mol $\mathrm{l}^{-1} \mathrm{MeJA}$ solution for $30 \mathrm{~s}$ prior to storage. ${ }^{28,29}$

\section{Disease incidence}

Disease incidence was observed in around $60 \%$ of the untreated fruit, whereas it was significantly $(P<0.05)$ reduced in fruit treated with prochloraz (26.9\%), MeJA at $10 \mu \mathrm{mol} \mathrm{l}^{-1}(27.5 \%)$ and $100 \mu \mathrm{mol} \mathrm{l}^{-1}(22.4 \%)$, or MeSA at $10 \mu \mathrm{mol}^{-1}(17.9 \%)$ and $100 \mu \mathrm{mol}^{-1}(16.4 \%)$. This observation is not surprising since chilling injured fruit are often more susceptible to fungal infections. ${ }^{41}$ A slightly lower disease incidence in fruit exposed to MeSA could be associated with its ability to reduce the ethylene production. ${ }^{42}$

\section{Physical properties of the fruit}

All fruit were assessed at the 'ripe and ready to eat' stage - at firmness being in the range from 0.65 to 0.90 $\mathrm{kg}$, i.e. below $1 \mathrm{~kg}$, which according to the International Organization for Standards (ISO 7619) represents ripe fruit.

The storage of avocado fruit at low temperature may cause lenticels damage, however in the case of 'Hass' avocados exported to the UK, which are marketed as a 'ripe and ready to eat' fruit, this may not be a serious issue due to the fact that lenticels damage can only be noticed on green unripe fruit, while the product would be displayed on the market shelf when ripe (purple/black), so the external chilling injury would easily be masked. ${ }^{43}$ For this reason, and also because as mentioned before, the lack of internal defects being among the key aspects of avocado fruit quality that ensures consumers' satisfaction, ${ }^{16}$ this research focused on the internal appearance of the fruit. In terms of colour, the mesocarp of all the fruit treated with either MeJA or MeSA was lighter (higher $L^{*}$ value), greener (lower $a^{*}$ value) and more yellow (higher $b^{*}$ value) than untreated control (Table 1), further confirmed by the higher $h u e^{\circ}$ value, while in comparison with the fruit treated with prochloraz the differences were less pronounced. This could be related to the lower incidence and severity of mesocarp browning caused by chilling injury (Fig. 2A) or postharvest decay in those fruit when compared with the severely affected untreated control. Reduced mesocarp browning is in agreement with previously reported studies, where loquat fruit were exposed to MeJA at $10 \mu \mathrm{mol} \mathrm{1^{-1 }}$ for $24 \mathrm{~h},{ }^{44}$ and peaches were exposed to MeJA at $1 \mu \mathrm{mol} \mathrm{l}{ }^{-1}$ for $24 \mathrm{~h}^{45,46}$ or $16 \mu \mathrm{mol} \mathrm{l}^{-1}$ for $6 \mathrm{~h},{ }^{47}$ before being subsequently stored at $0-1{ }^{\circ} \mathrm{C}$. 


\section{Fruit biochemistry}

Phenolic acids, activity of PAL and PPO

Mesocarp browning is one of the main causes of quality loss, ${ }^{16}$ especially during the storage at low temperature. ${ }^{14,15}$ The key components involved in this process are phenylalanine ammonia-lyase (PAL; EC 4.3.1.5) involved in the biosynthesis of phenolic compounds, phenolics content, polyphenol oxidase (PPO; EC 1.14.18.1) activity, and loss of tissue integrity ${ }^{48,49}$ because the substrates and enzymes are separated from each other by being in a different cellular compartments, thus tissue browning does not progress until the membrane integrity is reduced, and they come into contact.

The activity of PAL (Fig. 3) and also PAL gene expression (Fig. 4) were increased in fruit treated with prochloraz, and MeJA or MeSA at $100 \mu \mathrm{mol} \mathrm{l}^{-1}$ but not in those treated at $10 \mu \mathrm{mol} \mathrm{l}^{-1}$, which would suggest that phenolics biosynthesis would be higher in these samples. Phenolic compounds improve the antioxidant capacity and reactive oxygen species (ROS) scavenging activity, thus they could also contribute to reduced susceptibility to chilling damage. ${ }^{44}$

The exposure to both MeJA and MeSA affected the composition of individual phenolic compounds in the avocado fruit. Exposure to MeJA at $100 \mu \mathrm{mol} \mathrm{l}^{-1}$ resulted in significantly higher content of pyrogallol, caffeic acid, and hydroxybenzoic acid, while the content of protocatechuic acid was lower when compared with untreated fruit and those treated with prochloraz prior to storage (Table 2). Similar effect was observed in fruit exposed to MeSA at $10 \mu \mathrm{mol} \mathrm{l}^{-1}$ and $100 \mu \mathrm{mol} \mathrm{l}^{-1}$ but not in those exposed to MeJA at $10 \mu \mathrm{mol} \mathrm{l}^{-1}$ (Table 2), where only the pyrogallol content was higher while other phenolics were not affected. The lowest content of pyrogallol observed in control and prochloraz treated fruit could be to some extent explained by pyrogallol being used as a substrate by polyphenol oxidase (PPO) and peroxidase (POD) leading to tissue browning as indicated by higher chilling index, ${ }^{17,50}$ especially taking into account high affinity of PPO for pyrogallol. The content of $p$-coumaric acid and ferrulic acid, which usually increase during the fruit ripening, ${ }^{51}$ was not affected by the treatments, suggesting that fruit were likely at the same ripeness stage.

On the other hand the activity of PPO was highest in the control fruit, while in all other treatments, with an exception of MeJA at $10 \mu \mathrm{mol} \mathrm{l}^{-1}$ that had no effect, the activity of PPO was significantly reduced (Fig. 5). The ability of salicylate to reduce the activity of PPO and POD has recently been reported. ${ }^{52}$ Highest activity of PPO, assuming reduced tissue integrity being in place, ${ }^{53}$ would definitely be responsible for the severe mesocarp browning in untreated fruit. ${ }^{6}$ 
Care needs to be taken when directly comparing the activity of these enzymes among the treatments, because as indicated by chilling injury incidence and severity, the tissue integrity was not the same. Thus, even though the higher activity of PPO led to severe tissue browning in untreated fruit, this might not necessary be the case in the fruit exposed to MeJA at $10 \mu \mathrm{mol} \mathrm{l}^{-1}$; chilling injury incidence was indeed higher in these samples when compared to their counterparts exposed to MeJA at $100 \mu \mathrm{mol} \mathrm{l}^{-1}$ and MeSA at $10 \mu \mathrm{mol} \mathrm{l}^{-1}$ and $100 \mu \mathrm{mol} \mathrm{l}^{-1}$, but much lower than in case of untreated fruit and those treated with prochloraz (Fig. 2A). Improved membrane integrity has in fact been reported for numerous produce treated with jasmonates and salicylates prior to cold storage, e.g. in loquat treated with MeJA at $10 \mu$ mol $1^{-1}$ for 24 h, stored at $1{ }^{\circ} \mathrm{C},{ }^{20}$ pomegranates treated with MeJA and MeSA at 10 and $100 \mu$ mol $1^{-1}$ for $16 \mathrm{~h}$, stored at 2 ${ }^{\circ} \mathrm{C},{ }^{27}$ and tomatoes treated with MeSA at $50 \mu \mathrm{mol} \mathrm{l}^{-1}$ for $12 \mathrm{~h}$, stored at $2{ }^{\circ} \mathrm{C} .{ }^{54}$

Fatty acids

Total fatty acids content was found to be significantly reduced in untreated $\left(102.56 \mathrm{~g} \mathrm{~kg}^{-1}\right)$ and prochloraz $\left(105.53 \mathrm{~g} \mathrm{~kg}^{-1}\right)$ treated fruit, compared with those treated with MeJA at $10 \mu \mathrm{mol} \mathrm{l}{ }^{-1}\left(121.49 \mathrm{~g} \mathrm{~kg}^{-1}\right)$ and 100 $\mu \mathrm{mol} \mathrm{l}^{-1}\left(122.56 \mathrm{~g} \mathrm{~kg}^{-1}\right)$, and also those exposed to MeSA at $10 \mu \mathrm{mol} \mathrm{l} \mathrm{l}^{-1}\left(118.85 \mathrm{~g} \mathrm{~kg}^{-1}\right)$ and $100 \mu \mathrm{mol} \mathrm{l} \mathrm{l}^{-1}$ (124.03 $\left.\mathrm{g} \mathrm{kg}^{-1}\right)$, respectively. The lower fatty acids content in untreated and prochloraz treated fruit could be a result of lipid degradation ${ }^{53,55}$ due to excess ROS production.

The main fatty acid identified in avocado fruit was oleic acid (18:1). The higher proportion of monounsaturated fatty acids is in agreement with the published literature. ${ }^{56-58}$ There was a clear effect of MeJA and MeSA exposure on individual fatty acid composition (Table 3), where oleic acid content was increased. In case of the other fatty acids MeJA and MeSA affected them in a different way. In 'Hass' avocado fruit exposed to MeJA the content of palmitic acid $(16: 0)$ was significantly $(P<0.05)$ lower, while linolenic acid (18:2) was slightly but not significantly higher when compared with untreated fruit and those treated with MeSA. This led to unsaturated: saturated fatty acids ratio being significantly higher in MeJA exposed fruit compared with all the other treatments. Similar observation has recently been reported in olives exposed to MeJA prior to storage. ${ }^{59}$ On the other hand, in avocado fruit exposed to MeSA, only oleic acid (18:1) content was significantly $(P<0.05)$ increased compared to untreated and prochloraz treated fruit, whereas linoleic acid (18:2) was not affected, which led to the highest monounsaturated: polyunsaturated ratio in those samples, especially where MeSA was applied at $100 \mu \mathrm{mol} \mathrm{l}^{-1}$. These changes would surely affect the stability of membranes, since at low temperature membranes need to have higher content of unsaturated fatty acids to maintain their functionality. ${ }^{60,61}$ 
It is well known that high LOX activity would lead to reduced membrane integrity during the chilling stress. LOX gene expression was significantly down-regulated in all the fruit treated with either MeJA or MeSA, especially at $100 \mu \mathrm{mol} \mathrm{l}^{-1}$ (Fig. 6); similar trend was observed for the LOX activity. These results are in agreement with previously reported findings from avocados dipped in $2.5 \mu$ mol $1^{-1} \mathrm{MeJA}$ solution for $30 \mathrm{~s}$ and subsequently stored at $1{ }^{\circ} \mathrm{C}^{28}$ and loquat exposed to $10 \mu \mathrm{mol} \mathrm{l}^{-1} \mathrm{MeJA}$ for $24 \mathrm{~h}$ prior to storage at $1{ }^{\circ} \mathrm{C},{ }^{44}$ and highlight the ability of these treatments to alter membrane stability.

D-mannoheptulose, (C7 sugar), is known to be the main sugar in avocado fruit, ${ }^{36,62}$ whereas fructose and glucose that are often found in majority of fruit, have been reported to be only present at very low concentrations in avocados. ${ }^{36}$ There was no significant difference in the content of D-mannoheptulose between untreated control, and either prochloraz treated fruit or those exposed to MeSA at $10 \mu \mathrm{mol}^{-1}$ and $100 \mu \mathrm{mol} \mathrm{l^{-1 }}$. However, significantly $(P<0.05)$ higher content of D-mannoheptulose was observed in fruit exposed to MeJA at $100 \mu \mathrm{mol} \mathrm{l}^{-1}$ (Table 4), while at $10 \mu \mathrm{mol}^{-1}$ the content of D-mannoheptulose was only slightly and not significantly higher than in control fruit. This could be associated with differences in the membrane stability as fruit biochemistry (PAL, phenolics and fatty acid composition) and chilling index were not exactly the same for fruit treated with MeJA at $10 \mu \mathrm{mol} \mathrm{l}^{-1}$ and $100 \mu \mathrm{mol} \mathrm{l}^{-1}$.

It has been previously suggested that higher content of D-mannoheptulose is responsible for delayed ripening since higher content of this sugar was reported for unripe and ripening fruit compared with the 'ripe and ready to eat' fruit. ${ }^{36,56,63,64}$ This finding was further confirmed in fruit exposed to 1-MCP, where ripening was inhibited/delayed and D-mannoheptulose was maintained at higher level. ${ }^{36}$ Thus, even though in this research the D-mannoheptulose content was found to be significantly higher in one of the treatments (MeJA at $100 \mu \mathrm{mol} \mathrm{l}^{-1}$ ) it is unlikely that the fruit were at different stage of ripeness, based on the physical properties, i.e. firmness and flesh colour (Table 1) of the fruit were not that different among the treatments. Furthermore, Pedreschi et al. ${ }^{4}$ has recently found no direct correlation between the content of D-mannoheptulose and time to reach edible ripeness in the 'Hass' avocado fruit.

\section{CONCLUSIONS}

Exposure of 'Hass' avocado fruit to methyl jasmonate (MeJA) and methyl salicylate (MeSA) vapours, especially at $100 \mu \mathrm{mol} \mathrm{l}^{-1}$ for $24 \mathrm{~h}$ prior to storage at $2{ }^{\circ} \mathrm{C}$ reduced their susceptibility to chilling injury. The findings from this research highlight the potential of these treatments for being used if 'Hass' avocado fruit are to be shipped at low temperature. Their mode of action is based on the ability of these treatments to alter membrane integrity and fatty acids content/composition via down-regulating the activity of LOX. 
Future studies, however should focus on studying, in more depth, the effects of MeJA and MeSA exposure on the functionality of cell membranes in avocado fruit stored at low temperature, i.e. $1-2{ }^{\circ} \mathrm{C}$ to better understand the exact mechanism of action for these signalling compounds, as membranes are the primary sites for development of chilling injury.

\section{ACKNOWLEDGEMENTS}

The financial assistance for the first authors visit to South Africa to conduct the trials was funded by the DST-NRF (National Research Foundation) Fellowship for early career researchers from the UK jointly with the SARChi research chair grant for Phytochemical Food Network to Improve Nutritional Quality for Consumers, Grant number 98352. Opinions expressed and conclusions arrived at, are those of the authors and are not necessarily to be attributed to the NRF.

\section{REFERENCES}

1 Dreher M and Davenport A, Hass avocado composition and potential health effects. Crit Rev Food Sci Nutr 53: 738-750 (2013).

2 Ozdemir F and Topuz A, Changes in dry matter, oil content and fatty acids composition of avocado during harvesting time and post-harvesting ripening period. Food Chem 86: 79-83 (2004).

3 Lu QY, Zhang Y, Wang Y, Lee RP, Gao K, Byrns R and Heber D, California Hass avocado. Profiling of carotenoids, tocopherols, fatty acids, and fat content during maturation and from different growing areas. $J$ Agric Food Chem 57: 10408-10413 (2009).

4 Pedreschi R, Munoz P, Robledo P, Becerra C, Defilippi B, Van Eekelen H, Mumm R, Westra E and Vos R, Metabolomics analysis of postharvest ripening heterogeneity of 'Hass' avocadoes. Postharvest Biol Technol 92: 172-179 (2014).

5 Dodd M, Cronje P, Taylor M, Huysamer M, Kruger F, Lotz E and van der Merwe K, A review of the post harvest handling of fruits in South Africa over the past twenty five years. S Afr J Plant Soil 27: 97-116 (2010).

6 Hershkovitz V, Saguy SI and Pesis E, Postharvest application of 1-MCP to improve the quality of various avocado cultivars. Postharvest Biol Technol 37: 252-264 (2005).

7 Kruger FJ and Lemmer D, Commercialization of SmartFresh ${ }^{\mathrm{SM}}$ (1-Methylcyclopropene; 1-MCP) in the South African avocado industry. S Afr Fruit J 2/3: 51-55 (2011).

8 Nelson RM, Quality challenges facing the South African avocado industry - An overview of the 2009 South African avocado season. SAAGA Yearb 33: 7-13 (2010). 
9 Nunes MCN, Correlations between subjective quality and physicochemical attributes of fresh fruits and vegetables. Postharvest Biol Technol 107: 43-54 (2015).

10 Glowacz M and Rees D, The practicality of using ozone with fruit and vegetables. J Sci Food Agric 96: 4637-4643 (2016).

11 Adkins MF, Hofman PJ, Stubbings BA and Macnish AJ, Manipulating avocado fruit ripening with 1methylcyclopropene. Postharvest Biol Technol 35: 33-42 (2005).

12 Palou L, Jacas JA, Marcilla A, Alonso M and del Rio MA, Physico-chemical and sensory quality of 'Clemenules' mandarins and survival of the Mediterranean fruit fly as affected by complementary cold and carbon dioxide quarantine treatments. Postharvest Biol Technol 48: 443-450 (2008).

13 Pesis E, Ackerman M, Ben-Arie R, Feygenberg O, Feng X, Apelbaum A, Goren R and Prusky D, Ethylene involvement in chilling injury symptoms of avocado during cold storage. Postharvest Biol Technol 24: 171-181 (2002).

14 Woolf AB, Cox KA, White A and Ferguson IB, Low temperature conditioning treatments reduce external chilling injury of 'Hass' avocados. Postharvest Biol Technol 28: 113-122 (2003).

15 Gudenschwager O, Garcia-Rojas M, Defilippi BG and Gonzalez-Aguero M, Identification and characterization of two putative genes encoding acetyl-coenzyme A carboxylase subunits that are possibly associated with internal browning during cold storage of 'Hass' avocados (Persea americana Mill.). Postharvest Biol Technol 84: 74-80 (2013).

16 Gamble J, Harker FR, Jaeger SR, White A, Bava C, Beresford M, Stubbings B, Wohlers M, Hofman PJ, Marques R and Woolf A, The impact of dry matter, ripeness and internal defects on consumer perceptions of avocado quality and intentions to purchase. Postharvest Biol Technol 57: 35-43 (2010).

17 Gomez-Lopez VM, Some biochemical properties of polyphenol oxidase from two varieties of avocado. Food Chem 77: 163-169 (2002).

18 Glowacz M and Rees D, Using jasmonates and salicylates to reduce losses within the fruit supply chain. Eur Food Res Technol 242: 143-156 (2016).

19 Gonzalez-Aguilar GA, Tiznado-Hernandez ME, Zavaleta-Gatica R and Martinez-Tellez MA, Methyl jasmonate treatments reduce chilling injury and activate the defense response of guava fruits. Biochem Biophys Res Commun 313: 694-701 (2004).

20 Cao S, Zheng Y, Wang K, Rui H and Tang S, Effect of methyl jasmonate on cell wall modification of loquat fruit in relation to chilling injury after harvest. Food Chem 118: 641-647 (2010). 
21 Cai Y, Cao S, Yang Z and Zheng Y, MeJA regulates enzymes involved in ascorbic acid and glutathione metabolism and improves chilling tolerance in loquat fruit. Postharvest Biol Technol 59: 324-326 (2011). 22 Gonzalez-Aguilar GA, Fortiz J, Cruz R, Baez R and Wang CY, Methyl jasmonate reduces chilling injury and maintains postharvest quality of mango fruit. J Agric Food Chem 48: 515-519 (2000).

23 Gonzalez-Aguilar GA, Buta JG and Wang CY, Methyl jasmonate reduces chilling injury symptoms and enhances colour development of 'Kent' mangoes. J Sci Food Agric 81: 1244-1249 (2001).

24 Gonzalez-Aguilar GA, Buta JG and Wang CY, Methyl jasmonate and modified atmosphere packaging (MAP) reduce decay and maintain postharvest quality of papaya 'Sunrise'. Postharvest Biol Technol 28: 361-370 (2003).

25 Wang L, Chen S, Kong W, Li S and Archbold DD, Salicylic acid pretreatment alleviates chilling injury and affects the antioxidant system and heat shock proteins of peaches during cold storage Postharvest Biol Technol 41: 244-251 (2006).

26 Meng X, Han J, Wang Q and Tian S, Changes in physiology and quality of peach fruits treated by methyl jasmonate under low temperature stress. Food Chem 114: 1028-1035 (2009).

27 Sayyari M, Babalar M, Kalantari S, Martinez-Romero D, Guillen F, Serrano M and Valero D, Vapour treatments with methyl salicylate or methyl jasmonate alleviated chilling injury and enhanced antioxidant potential during postharvest storage of pomegranates. Food Chem 124: 964-970 (2011).

28 Sivankalyani V, Feygenberg O, Maorer D, Zaaroor M, Fallik E and Alkan N, Combined treatments reduce chilling injury and maintain fruit quality in avocado fruit during cold quarantine. PLoS ONE 10: 1$16(2015)$.

29 Meir S, Philosoph-Hadas S, Lurie S, Droby S, Akerman M, Zauberman G, Shapiro B, Cohen E and Fuchs Y, Reduction of chilling injury in stored avocado, grapefruit, and methyl jasmonate. Can J Bot 74: 870-874 (1996).

30 Bill M, Sivakumar D, Beukes M and Korsten L, Expression of pathogenesis-related (PR) genes in avocados fumigated with thyme oil vapours and control of anthracnose. Food Chem 194: 938-943 (2016). 31 Mpho M, Sivakumar D, Sellamuthu PS and Bautista-Banos, S, Use of lemongrass oil and modified atmosphere packaging on control of anthracnose and quality maintenance in avocado cultivars. J Food Qual 36: 198-208 (2013).

32 Abbott JA, Quality measurement of fruits and vegetables. Postharvest Biol Technol 15: 207-225 (1999). 
33 Sellamuthu PS, Mafune M, Sivakumar D and Soundy P, Thyme oil vapour and modified atmosphere packaging reduce anthracnose incidence and maintain fruit quality in avocado. J Sci Food Agric 93: 30243031 (2013).

34 Zhang K and Zuo Y, GC-MS determination of flavonoids and phenolic and benzoic acids in human plasma after consumption of cranberry juice. J Agric Food Chem 28: 222-227 (2004).

35 Soliva RC, Elez P, Sebastian M and Martin O, Evaluation of browning effect on avocado puree preserved by combined methods. Innov Food Sci Emerg Technol 1: 261-268 (2001).

36 Meyer M and Terry L, Development of a rapid method for the sequential extraction and subsequent quantification of fatty acids and sugars from avocado mesocarp tissue. J Agric Food Chem 56: 7439-7445 (2008).

37 Maalekuu K, Elkind Y, Leikin-Frenkel, A., Lurie S and Fallik E, The relationship between water loss, lipid content, membrane integrity and LOX activity in ripe pepper fruit after storage. Postharvest Biol Technol 42: 248-255 (2006).

38 Bradford MM, A new method of protein determination. Anal Biochem 72: 248-251 (1976).

39 Roessner U, Wagner C, Kopka J, Trethewey RN and Willmitzer L, Simultaneous analysis of metabolites in potato tuber by gas chromatography-mass spectrometry. Plant J 23: 131-142 (2000).

40 Bill M, The role of postharvest thyme oil-based alternatives on simulated induction of defense mechanisms in avocado (Persea americana Mill.) for the control of anthracnose. PhD thesis. University of Pretoria, South Africa (2009).

41 Sevillano L, Sanchez-Ballesta MT, Romojaro F and Flores FB, Physiological, hormonal and molecular mechanisms regulating chilling injury in horticultural species. Postharvest technologies applied to reduce its impact. J Sci Food Agric 89: 555-573 (2009).

42 Yin X, Zhang Y, Zhang B, Yang S, Shi Y, Ferguson IB and Chen K, Effects of acetylsalicylic acid on kiwifruit ethylene biosynthesis and signaling components. Postharvest Biol Technol 83: 27-33 (2013).

43 Everett KR, Hallett IC, Rees-George J, Chynoweth RW and Pak HA, Avocado lenticel damage: The cause and the effect on fruit quality. Postharvest Biol Technol 48: 383-390 (2008).

44 Cao S, Zheng Y, Wang K, Jin P and Rui H, Methyl jasmonate reduces chilling injury and enhances antioxidant enzyme activity in postharvest loquat fruit. Food Chem 115: 1458-1463 (2009).

45 Jin P, Zheng Y, Tang S, Rui H and Wang CY, A combination of hot air and methyl jasmonate vapor treatment alleviates chilling injury of peach fruit. Postharvest Biol Technol 52: 24-29 (2009). 
46 Jin P, Wang K, Shang H, Tong J and Zheng Y, Low-temperature conditioning combined with methyl jasmonate treatment reduces chilling injury of peach fruit. J Sci Food Agric 89: 1690-1696 (2009).

47 Jin P, Duan Y, Wang L, Wang J and Zheng Y, Reducing chilling injury of loquat fruit by combined treatment with hot air and methyl jasmonate. Food Bioprocess Technol 7: 2259-2266 (2014).

48 Martinez MV and Whitaker JR, The biochemistry and control of enzymatic browning. Trends Food Sci Technol 6: 195-200 (1995).

49 Singh R, Rastogi S and Dwivedi UN, Phenylpropanoid metabolism in ripening fruits. Compr Rev Food Sci Food Saf 9: 398-416 (2010).

50 Cheema S and Sommerhalter M, Characterization of polyphenol oxidase activity in Ataulfo mango. Food Chem 171: 382-387 (2015).

51 Hurtado-Fernandez E, Pacchiarotta T, Mayboroda OA, Fernandez-Gutierrez A and Carrasco-Pancorbo A, Quantitative characterization of important metabolites of avocado fruit by gas chromatography coupled to different detectors (APCI-TOF MS and FID). Food Res Int 62: 801-811 (2014).

52 Zhou D, Li L, Wu Y, Fan J and Ouyang J, Salicylic acid inhibits enzymatic browning of fresh-cut Chinese chestnut (Castanea mollissima) by competitively inhibiting polyphenol oxidase. Food Chem 171: $19-25$ (2015).

53 Marangoni AG, Palma T and Stanley DW, Membrane effects in postharvest physiology. Postharvest Biol Technol 7: 193-217 (1996).

54 Zhang X, Shen L, Li F, Meng D and Sheng J, Methyl salicylate-induced arginine catabolism is associated with up-regulation of polyamine and nitric oxide levels and improves chilling tolerance in cherry tomato fruit. J Agric Food Chem 59: 9351-9357 (2011).

55 Wang CY, Kramer GF, Whitaker BD and Lusby WR, Temperature preconditioning increases tolerance to chilling injury and alters lipid composition in zucchini squash. J Plant Physiol 140: 229-235 (1992).

56 Donetti M and Terry L, Biochemical markers defining growing area and ripening storage of imported avocado fruit cv. Hass. J Food Comp Anal 34: 90-98 (2014).

57 Garcia-Rojas M, Morgan A, Gudenschwager O, Zamudio S, Campos-Vargas R, Gonzalez-Aguero M and Defilippi BG, Biosynthesis of fatty acids-derived volatiles in 'Hass' avocado is modulated by ethylene and storage conditions during ripening. Sci Hort 202: 91-98 (2016). 
58 Pedreschi R, Hollak S, Harkema H, Otma E, Robledo P, Westra E, Somhorst D, Ferreyra R and Defilippi BG, Impact of postharvest ripening strategies on 'Hass' avocado fatty acid profiles. S Afr J Bot 103: 32-35 (2016)

59 Flores G, Blanch GP and Ruiz del Castillo ML, Effect of postharvest methyl jasmonate treatment on fatty acid composition and phenolic acid content in olive fruits during storage. J Sci Food Agric DOI: 10.1002/jsfa.8104 (2017).

60 Badea $\mathrm{C}$ and Basu SK, The effect of low temperature on metabolism of membrane lipids in plants and associated gene expression. Plant Omics J 2: 78-84 (2009).

61 Cao S, Yang Z, Cai Y and Zheng Y, Fatty acid composition and antioxidant system in relation to susceptibility of loquat fruit to chilling injury. Food Chem 127: 1777-1783 (2011).

62 Liu X, Sievert J, Arpaia ML and Madore M, Postulated physiological roles of the seven carbon sugars, mannoheptulose and perseitol in avocado. J Am Soc Hortic Sci 127: 108-114 (2002).

63 Landahl S, Meyer M and Terry L, Spatial and temporal analysis of textural and biochemical changes of imported avocado cv. Hass during fruit ripening. J Agric Food Chem 57: 7039-7047 (2009).

64 Obenland D, Collin S, Sievert J, Negm F and Arpaia ML, Influence of maturity and ripening on aroma volatiles and flavor in 'Hass' avocado. Postharvest Biol Technol 71: 41-50 (2012). 